\title{
Towards Māori Corporate Social Responsibility
}

\begin{abstract}
This paper explores the potential interface between Māori collectively-owned organisations, and those organisations and businesses that practice corporate social responsibility (CSR). The literature suggests that CRS is good for business; that it is possible to achieve a double bottom line on social and financial performance. These performance outcomes will be of particular interest to Māori collectively-owned organisations charged with growing tribal wealth, as well as delivering better social outcomes to their beneficiaries. Recently, as a result of the Treaty of Waitangi claims processes, Māori tribal organisations have proliferated. These tribal organisations have consequently adopted governance arrangements designed to deliver both commercial and social outcomes. Additionally, they are expected to incorporate Māori culturally specific values that ultimately underpin the governance of the organisation. Beneficiaries of most Māori collective organisations are members of the tribe that have recognised genealogical links to a founding ancestor. Tribal organisations are consequently becoming increasingly responsible for the financial, social, cultural and environmental wellbeing of the tribe. Furthermore, the management of tribal assets to enhance tribal wellbeing is embedded in the notion of sustainability - specifically intergenerational wealth creation.
\end{abstract}

Keywords: Indigenous, Māori, Corporate social responsibility, Treaty 


\section{INTRODUCTION}

Some 600 years ago Machiavelli, the Italian Renaissance statesman, reasoned that the survival of a state was dependant on fostering patriotism and 'civic virtue.' The connotations or values associated with civic virtue; honesty, justice, and service to the community inform corporate social responsibility (CSR). In fact, CSR principles for most organisations go beyond service to the state and include human rights, ethics, community support and protecting the environment. Having established the relationship between civic virtue and its modern manifestation, CSR, it is time to examine Machiavelli's position on 'civic virtue.' His stance on this matter is astounding given that he is better known as the architect of a political theory that is the antithesis of 'civil virtue.' In his most famous work, The Prince he advocates treachery, duplicity and intrigue, as essential tools for effective governance. Unsurprisingly this more orthodox Machiavellian approach to social responsibility has not been lost on CSR detractors.

'CSR will always be mere window dressing. In some cases, the same company that devotes a penny to CSR spends 99 cents on moneymaking projects that make social problems worse. This is not a formula for improving society...' (Yunus, 2008 p.25).

While this may be true, it does raise the question: Are companies who use CSR as a front for exploitation really in the business of social responsibility? Using CSR as a façade for profit maximisation is contrary to the principles of CSR and in fact aligns more closely with Milton Friedman's (1962) views on social responsibility

'...there is one and only one social responsibility of business-to use it resources and engage in activities designed to increase its profits so long as 
it stays within the rules of the game, which is to say, engages in open and free competition without deception or fraud' (p.133).

Milton Friedman is a recipient of the acclaimed Nobel Prize Laureate in Economics. Amartya Sen, an equally reputable economist, is a recipient of the same prize. That is perhaps where the similarity ends. Both economists have very different and contrary positions on social responsibility. Amartya Sen, (1987) explores the relationship between ethics and economics. 'Economics, as it has emerged, can be made more productive by paying greater and more explicit attention to the ethical considerations that shape human behaviour and judgment' (p.9).

Surprisingly, to support his ethical business position, Sen, draws on the work of the Enlightenment economist Adam Smith, widely regarded as the father of free market capitalism. In this respect Sen is not alone in defending Smith's economic theory which sets an agenda not dissimilar to the modern CSR one - that social responsibility should not impede profitability and this approach inevitably leads to social justice.

...anyone who cares to read Smith's Wealth of Nations for themselves will find an economics discussed and justified in explicitly moral terms, in which markets, and the division of labour they allow, are shown to both depend upon and produce not only prosperity but also justice and freedom, particularly for the poor. (Wells, 2014 pp.90 - 91).

The tension between self-interest and altruism is a feature of Adam Smith's writing. While there appears to be a contradiction between his two works: The Wealth of Nations and Theory of Moral Sentiments the ambiguity is a result of misinterpretation (Griswold 1999; Sen, 1987; Wells, 2014). This excerpt, published in 1759 , is decidedly unambiguous. 
How selfish soever man may be supposed, there are evidently some principles in his nature, which interest him in the fortune of others, and render their happiness necessary to him, though he derives nothing from it except the pleasure of seeing it (p9).

That said there is no doubt that in regards to the CSR agenda there is a fine line between social responsibility and selfinterest. Ironically it is this paradox that makes CSR such a viable proposition for business. 'Arguments in favour of CSR typically begin with the belief that it is in business's long term interest - enlightened self-interest - to be socially responsible' (Carroll \& Shabana 2010 pp.88-89). If the basic principle of social responsibility is applied to practice, it can be argued that the rationale or motivation for incorporating CSR principles, whether altruistic or purely for profit, is a moot point. This is because social responsibility appears to be not only good for business, but also good for the community - and for many CSR advocates, also for the environment (Arena, 2004; Jackson, 2004; Hopkins, 2003; Russo \& Fouts, 1997).

It would also be remiss to ignore the fact that CSR's ability to generate profitability is vigorously contested (Henderson 2001; Reich 2008; Friedman, 1962; May, Cheney and Roper 2007; Parva, \& Krausz 1995; Vogel 2005). This criticism cannot be easily dismissed - despite the fact that proponents of CSR have reported an increase in profit margins of CSR and ethical business organisations (Arena, 2004; Jackson, 2004; Poitras, 1994; Russo \& Fouts 1997; Willard, 2002; Young and Tilley, 2006). It is feasible that increased surplus is enough incentive for organisations to consider a CSR agenda. However, in the absence of reliable instruments to accurately measure CSR profit margins, it is apparent that a CSR agenda delivers 'immeasurable' intrinsic rewards. 
Companies around the world...have recognized that corporate social responsibility has inherent value for a company. The exact dollar figure on that value may never be clearly quantified but the general trend toward greater corporate engagement in social issues is one that will have long-term impacts on the development community. (Whaley 2013, p.1)

\section{MĀORI TRIBAL ORGANISATIONS}

CSR also presents a way forward for Māori tribal organisations to advance tribal wellbeing. The United Nations Special Rapporteur Rodolfo Stavenhagen succinctly frames Māori and their relationship with the Crown within the Treaty of Waitangi.

The relations between Maori, the indigenous people of New Zealand, and the Government are based on the Treaty of Waitangi signed in 1840. As a result of land sales and breaches of the Treaty by the Crown, Maori lost most of their land, resources, self-governance and cultural identity. A new approach since 1975 has led to numerous settlements of Maori land claims and the enactment of new legislation (Stavenhagen, 2006 p.2).

In actuality as a result of this 'new approach' the majority of Māori tribal organisations are post-Treaty Settlement entities (PSGE). These governance entities are established as part of the NZ Treaty of Waitangi claims settlement process. PSGE tribal organisations differ from most because other organisations because their governance boards are not accountable to shareholders (or stockholders).

Instead governance boards of Māori PSGE tribal organisations are accountable to beneficiaries. Members of the 
tribe are beneficiaries of tribal assets, which primarily derive from settlement of the tribe's historic Treaty claims against the government. PSGE's are responsible to beneficiaries rather than shareholders, which makes governance less clear for tribal organisations. Despite this challenge the expectation of the members of tribal beneficiaries (like shareholders), is that the organisation will grow tribal wealth. The difference is tribal wealth is not confined to financial growth. Beneficiaries require Māori collective organisations to aspire to and value the spirit and principles of the culture. In this respect Māori tribal organisations need to realise a triple bottom line - by adding cultural sustainability to their outputs. Indeed, it is the capacity to achieve a double bottom line on social and financial performance that will be of most interest to Māori collective organisations.

Because the criteria of Māori collective organisation membership is whakapapa (kinship), the notion of rights and responsibilities, inherent in such structures, should inform Māori collective organisations - especially at a governance level. In this respect it is actually incumbent on Māori collective organisations to integrate culturally specific beliefs and values into their governance arrangements. In fact, cultural and social responsibility imperatives are at the core of Māori collective organisational governance arrangements simply because social responsibility is intrinsic to Māori cultural beliefs and practices.

The cultural value sets that inform social responsibility are embedded in the Māori world view. Cultural customs (tikanga) values (ngā uara) such as guardianship (kaitiakitanga), kindness (aroha), caring (manaakitanga) responsibility (kawenga) are commonly included in Māori governance practices. Whakapapa underpins these values and therefore shapes the way the Māori world is viewed. Māori collective organisations must therefore aspire to, and value the spirit and principles that define Māori culture.

Māori, share with many other many indigenous people, a traditional world-view that is holistic and is all encompassing. 
The Māori world begins with the creation narratives. Māori cosmology is defined by kinship. In traditional Māori thought, the entire universe is personified. The progenitors of life are primeval parents are the gods (ātua), Ranginui (sky) and Papatūānuku (earth). There is a Māori saying:

Nā Ranginui rāua ko Papatūānuku tāua

We are both descendants of the sky father and the earth mother

The natural environment, trees, waters animals and ultimately people are linked together through kinship. As such the Māori physical and spiritual world is defined through whakapapa. Consequently, Māori people believe that they are descendants of the gods. The spiritual aspect of their world is reinforced in the practice of karakia (prayers) which invoke the gods. In contemporary Māori life karakia is usually Christian. In traditional society the prayers invoked the most appropriate (to the occasion) gods.

There are (minor) tribal variations but all Māori creation narratives recognise the primeval parents Ranginui and Papatūānuku. At a tribal level, the focus is exclusively on tribal kinship ties to a common ancestor and their relationship with the land of their ancestors.

Māori groups who bring claims under the Treaty of
Waitangi Act 1975, are most often bonded by
blood. The usual common denominator of each
group is the ability of each member to whakapapa
to a common tūpuna (Law Commission 2002, p.4).

The relationship between the people and the land is best described in the Tūhoe tribal traditions. Tūhoe one of the largest tribes in New Zealand is recognised as the wealthiest (culturally) because they have successfully retained their language and traditional knowledge. Tūhoe narratives on their origins is 
reminiscent of the Ranginui and Papatūānuku traditions. According to Tūhoe traditions, the mountain (Te Maunga), married the atua (god) Hinepükohurangi, the mist maiden. They produced Pōtiki, the primeval ancestor of the people of Tūhoe. The mists cover most of Tühoe in the winter and the tribe is affectionately referred to as the 'children of the mist.' This is an obvious reference to Hinepūkohurangi.

Tūhoe also see the rivers and tributaries that traverse their tribal estates as 'te uaua toto o Papatūannuku- the veins of Papatūānuku (Hohepa Kereopa, private communication 12 April 2001). Therefore, the relationship between Tūhoe to each other, and to the environment is defined through kinship. Much to the chagrin of many Māori, these traditions are considered by some as puerile.

Ki te Pākehā he kōrero pürākau he kōrero noiho. Ahakoa ki te Māori, he kōrero whakapapa, he kōrero tapu, tapu rawa atu.

To the European they are fairy tales just stories.

To the Māori they tell of our genealogy (kinship) and are sacred, very, very sacred. Hone Kaa (TVNZ 1988). ${ }^{1}$

Nevertheless, sacredness doesn't necessarily equate to godliness or indeed goodness. Māori traditions (like those of the ancient Greeks) depict the gods as both malevolent and virtuous. Therefore, the propensity for good and evil is a legacy from the gods that explains the human condition. Duality of opposites is a knowledge system that is fundamental to all, or most, societies. Drawing again on the ancient Greeks, Heraclitus (540-480BC) is recognised as the is recognised as the first philosopher to introduce the dialectic (theory of opposites). $\mathrm{He}$ is famous for the adage. 'If it were not for injustice, men

Television New Zealand Archive. (1988). Mokoia Waka Huia Documentary. 
would not know justice.' ${ }^{2}$ So the obvious question, in the context of social responsibility, is: How are positive beliefs and values reconciled with the not so positive ones?

Peter Senge (1990) in his seminal work on learning organisations, coined the term 'creative tension' to describe a process to bridge the gap between a vision and the current reality. Creative tension is dialectical praxis (bringing theory and practice together) that allows for exploration that, in the process, harnesses creative energy. The dialectic can be applied to Māori collective organisations and in particular the emphasis that the culture places on kinship relationships. The notion of kinship, entrenched as it is in Māori consciousness, serves as a reminder, that dialectically speaking, kinship relationships not only confer rights - but also responsibilities.

\section{GROWING TRIBAL WEALTH}

Spiller, Erakovic, Henare and Pio (2011) argue that responsibility is tied to the notion of giving having intrinsic rewards.

Contributing to a greater whole contributes to spiritual well-being by creating healthier workplaces and communities, and recognises the spiritual importance of making work meaningful. In serving others, one is serving one's extended self, and self-actualization occurs in relationship. (p.161).

This idea is reminiscent of Jeremy Bentham's utilitarianism, he 'emphasised that the interests of any society were the sum of the interests of the individuals in that society, but qualified this by arguing that collective as well as individual

2 Kahn (1979) describes Heraclitus work as 'a theory of language which sees ambiguity as a device for the expression of multiple meanings, and a vision of human life and death within the larger order of nature'. 
satisfaction (or utility) was of prime importance to this formula' (Moon, 2014 p.5). According to Moon, 'Benthamite' philosophies influenced British colonial policy on New Zealand in the 1930s which impacted on the Treaty of Waitangi. Today, the Treaty of Waitangi has become the unlikely catalyst for Māori collective organisations to develop governance principles that have the potential to transform Māori communities.

An unusual feature compared to other countries is that New Zealand pays explicit attention to cultural well-being alongside social, economic and environmental well-being. This practice reflects New Zealand's experience in grappling with present-day policy implications of its bicultural foundations in the 1840 Treaty of Waitangi (Dalziel, Matunga and Saunders, 2006 p.267).

For most Māori the Treaty is about the rights of the indigenous people and the responsibilities of the Crown. However, the distance been ideology and practice has been assiduously maintained since the Treaty was signed. Moreover, the Treaty is often, and erroneously, referred to as New Zealand's founding document. In actuality the founding document is the 1852 New Zealand Constitution Act. Notwithstanding, it is the Treaty that is the focus of contention for the tribes because, as an agreement, it abjectly failed in its promise to protect their resources (Walker 1989; Orange 2011). The failure of the Crown to meet its Treaty obligations culminated in the establishment the Waitangi Tribunal in 1975. The purpose of the Tribunal was to investigate Crown breaches. However, both the Waitangi Tribunal and the Treaty are not legally binding. As such the Tribunal's powers are limited to making recommendations to government.

Moreover, frustrated by the bureaucratic tardiness of the Tribunal, the tribes agitated for speedier processing of Treaty claims. Direct negotiation with the Crown in 1995 paved the 
way for Treaty settlements - a process has not been smooth. The United Nations Rapporteur, James Anaya (2011) reported that.

An overarching concern is that the negotiation procedure is flawed from the outset because the party responsible for the breaches of the Treaty of Waitangi-the Government-is wholly responsible for determining the framework policies and procedures for redress for those breaches, resulting in a situation that is inherently imbalanced and unfair to Māori (p.12).

Despite misgivings, the Crown compensation for Treaty breaches has provided an economic base for those tribes who have settled historic grievances. It is for that reason that most tribes have, albeit reluctantly and resentfully for many, opted to participate in the Treaty settlement process. In this process the Tribunal continues to be an important part of the Treaty of Waitangi settlement process is that their findings cannot easily be dismissed by the Crown. If there is disagreement the tribe can, and does, take the issue to the Tribunal to resolve. The Crown tends to assiduously avoid Tribunal hearings during tribal Treaty claims negotiations.

The perseverance of the tribes to settle historical Treaty claims has had positive outcomes for most tribes. In the mid1970's the former Minister of Justice, Sir Douglas Graham, (credited with accelerating the Treaty Settlement process) promoted the claims process as a vehicle for Māori to move 'from grievance mode to development mode' (Graham 1977 p. 49). If the article in The New Zealand Herald titled (September 3, 2011 ) 'The Rousing Giant of Maori Money' is any measure of the success of his vision - he must be very pleased.

The Herald article compared the fortunes of the two wealthiest (monetarily) tribes in New Zealand, Ngāi Tahu in the southern NZ and Tainui in the north. The article concluded that: 'With about 600,000 of New Zealand's 4.4 million 
population being Maori, iwi powerhouses like these have vast potential' (New Zealand Herald September 3, 2011). Since that time the wealth of both tribes, despite setbacks, has grown exponentially. This is evidenced in recent reports of the record growth of assets for most tribes based on Tainui's Treaty settlement redress which totalled \$NZ170 million). The impact of the settlement claim process has meant that Māori are being taken seriously as a major player in the New Zealand economy:

The Bank of New Zealand (BNZ) has created a new position - head of Maori business - as it eyes the near $\$ 3.7$ billion worth of 'Maori economy' assets following Treaty of Waitangi claim settlements (New Zealand Herald September 8, 2011).

A more recent Herald article reported more conservative estimates of Māori/iwi wealth generation: "Three trail-blazing iwi now have assets valued at $\$ 2.7$ billion but in the next few years, 30 to 40 will emerge with that financial firepower' (New Zealand Herald February 26, 2015). Irrespective, there is no contention that Māori/iwi wealth generation is significant.

However, at a governance level, the tension between growing tribal wealth and addressing the social needs of the people needs to be addressed. This tension can be described as a struggle between mana (esteem6) and money. The triumphant declarations of burgeoning tribal wealth suggest that profit is taking precedence over social wellbeing. Joseph Zammit-Lucia (2013) criticises this development. 'Businesses have lost their way by focusing on profit maximisation at any cost instead of building strong societies.... one of the greatest issues facing our societies today - the glorification of the financial and the economic to the detriment of everything else' (Guardian Professional). As the Treaty settlement phase in New Zealand history draws to a close, unwittingly perhaps, money is becoming the key performance indicator for Māori tribal organisations. The concern that tribal organisations would 
adopt business corporate models to facilitate performance was raised some nearly two decades ago.

... [d]ifferent concerns about modern tribal
governance structures have ... been raised in
connection with the emphasis on business models,
which appear to corporatise iwi. Tribal members
are aware of the corporations in Alaska which have
all but ousted traditional tribal structures and are
keen to avoid creating economically orientated
organisations which fail to capture the essential
cultural basis of the tribe (Durie 1998, p13).

Interestingly, the Crown has gone to great lengths to distance themselves from the accusation that they are responsible for imposing corporate models. It is solely the responsibility of the claimant group to develop a post settlement governance entity which meets that group's needs and purposes. (http://www.ots.govt.nz/). Ostensibly there is some flexibility around the tribal governance structures. However, '...while the Crown is relatively flexible in its approach to the choice of legal entity made by the settlement group, expression of tikanga is limited. Most entities were created without Māori values in mind. They instead derive from English law' (Law Commission 2002, p11). Nonetheless post-treaty settlement governance entities, (PSGE) must include social and commercial subsidiaries. This is requisite to tribes receiving settlement funds for historic claims against the Crown. 
Diagram 1. Post Treaty Governance Model Template (PSGE)

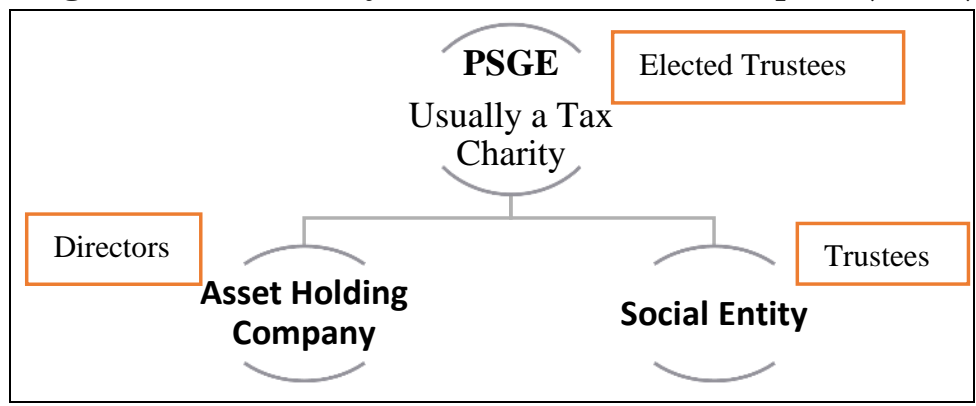

The organisation bodies must also describe any subsidiary bodies accountable to the governance entity such as asset management (commercial) and benefit distribution bodies (social). This dovetails into a conceivable CSR agenda with the potential to grow tribal wealth. Tribal wealth must be defined as economic, social, cultural, economic, environment and spiritual wellbeing. This concept of wealth holds the hope of improved social and financial outcomes for tribal beneficiaries. This aligns with Māori concepts of wealth which are holistic and synonymous with wellbeing or wellness.

Even today Māori still relate wellness to the deeper philosophical tradition linked to interrelationships between gods, the universe and all living things. McNeill, Aspin \& Te Kingi (2009) undertook a study on Māori health indicators, where many of those interviewed referred to Papatūānuku as the gauge of wellness. Most associated Papatūānuku with whakapapa particularly in relation the natural environment.

Mehemea kai te mãuiui a Papatūānuku, kai te māuiui tātau katoa. Ka pau haere ngā hua o te whenua, à, kāore kau hai oranga mō tātau te iwi.

If Papatūānuku is sick than we the people are sick. The resources of the land disappear and the people have sustenance. 
This poignant correlation between the health status of the land (Papatūānuku) and the people is linked to the colonial experience. Evidence to support this allegation can be found in documentation detailing Crown breaches of the Treaty - which are formally acknowledged as part of the settlement process. The following Crown apology is included in the Tapuika Deed of Settlement 2012.

Mai anō i ngā tau 1950, kua tāhawahawatia, kua whakaparuparutia hoki ngā wai a Parawhenuamea $e$ noho ai koutou, $e$ whakamaimoatia ai e koutou. E ngaukino ana te manawa pā $i$ te Karauna $i$ te auhī i pā ki a Tapuika, mōna $i$ kore nei e taurima i te hononga motuhake o Tapuika ki te Awa Nui o Tapuika me ōna hikuwai.

The waterways you live beside and cherish have, since the 1950s, been degraded and polluted. The Crown profoundly regrets the anguish this has caused for Tapuika, and failing to protect the special relationship Tapuika has with the Kaituna River and its tributaries (p.19).

Interestingly, the wording in the Treaty of Waitangi (clause 2 ) is explicit about ownership of the water ways.

'...the full exclusive and undisturbed possession of their Lands and Estates Forests Fisheries and other properties which they may collectively or individually possess.'

This has been a contentious issue for some time and resolved (legally) in 2013, when the Supreme Court, to the disappointment of the tribes, released its judgment in favour of the government. However, most tribes were not discouraged by 
the ruling because the cost of restoration of the waterways is prohibitive. The judgement also stated that it was incumbent on the government to remedy any breaches of the Treaty relating to water. Restoration of the natural environment is a priority for all of the tribes. For Māori the wellness of the river is paramount because whakapapa connects the tribe to the river - which in turn reinforces tribal identity and culture. This reference to the river is also included in the Tapuika Deed of Settlement.

In this sense it can be argued collective responsibility for the wellness of the natural environment as much the responsibility of the government as it is the tribe. The difference is that the tribes view this responsibility as kaitiakitanga. ${ }^{3}$ Caring for the environment benefits everyone. A healthy environment is necessary for the survival of all species. However, the earth's resources are finite and a short term profit driven approach to using environmental resources is unsustainable. Senge, Smith \& Kruschwitz et.al. (2010) argue that sustainability of the environment is a global dilemma which involves everyone. The basic tenet of their theory is that environmentally responsible businesses have the potential, not only to protect but to generate profit. Profit maximisation that safeguards the environment and thereby (indirectly) protects people is wealth creation - with prestige or mana. The notion of mana is of great significance to Māori and can be accrued without any reference to material wealth.

Tapuika is one of the smallest tribes in New Zealand and quite possibly one of the poorest (economically). However according to the latest Census figures $38.7 \%$ of Tapuika can speak the Māori language (te Reo). In comparison Ngāi Tahu, one the wealthiest (financially) tribes, report $11.2 \%$ speakers the language. (Statistics NZ, 2014). The data is based on NZ Census figures which uses self-assessment to determine fluency in te Reo. Although the Census methodology is problematic, it can be

3 'Caretakers' in this context of the natural environment, which as explained earlier is a relationship based on kinship through Papatūānuku and Ranginui. 
used as a loose indication of cultural wellbeing. Comparing the number of self-assessed Māori language speakers as an indicator of cultural wealth - Tapuika is wealthier than Ngāi Tahu. This raises an additional question: What is tribal wealth? Is it mana (prestige) or is it money?

Māori tribal organisations are on the whole quintessentially pragmatic and recognise that money and mana are both requisite to tribal wellbeing. This truism is expressed in the saying: Mã te hurhuru, ka rere te manu - Adorn the bird with feathers so it can fly. As already mentioned the main source of tribal capital is funds from Treaty claims against the Crown. In Māori thought there is a need to balance the physical (te taha kikokiko) and spiritual (te taha wairua) aspects of existence. However, the majority of tribal beneficiaries are typically poor. This creates additional challenges for Māori tribal organisations compelled to grow tribal wealth (material) and meet the expectation of better social outcomes to beneficiaries.

A recent World Bank sponsored study, claimed that 'Indigenous Peoples worldwide continue to be among the poorest of the poor and continue to suffer from higher poverty, lower education, and a greater incidence of disease and discrimination than other groups' (Hall \& Patrinos 2011). Applied to the New Zealand context, data from the last census reported: 'In 2013, the median income for all Māori aged 15 years and over was $\$ 22,500$ ' significantly less than the $\$ 28,500$ national median income (NZ Statistics 2014). The NZ government Treasury Report revealed that 'Māori in poverty are roughly double the Pākehā ${ }^{4}$ rate' (p.6). This problem is exacerbated when the reported growth of tribal assets and wealth is compared to overty indicators (such as health, education, housing etc.) of the tribe. Potentially, Māori tribal organisations face a creditability crisis amongst the people they are accountable to. Māori PSGE tribal organisations cannot ignore the unacceptable level of poverty of the majority of

4 Non-Māori usually European 
beneficiaries - neither can they be held solely responsible for addressing it.

Interestingly, "The traditional expectation has been that governments and the third sector are responsible for poverty alleviation' (Boyle \& Boguslaw 2007, p.101). The reality is, governments are not effective at addressing poverty - there is a plethora of evidence to support the claim that even in 'wealthy' nations, poverty is a constant. But as Yunnis (2008) argues:

Governments can do much to address social problems. They are large and powerful, with access to almost every corner of society, and through taxes they can mobilize vast resources. Even the governments of poor countries, where tax revenues are modest, can get international funds in the form of grants and low-interest loans. So it is tempting to simply dump our world's social problems into the lap of government (Yunnis 2008 p19).

It is feasible that a collaboration between CSR organisations and businesses, non-government organisations (NGO's), and government could provide a model that goes a long way to meeting the challenge of alleviating poverty.

CSR, by its very nature, is development done by the private sector, and it perfectly complements the development efforts of governments and multilateral development institutions. (Vivos 2004, p.46).

Business (or more accurately business with a conscience) is central to an inter-sectorial approach to tacking poverty.

Those living in poverty present great business opportunities for the private sector. They represent a market with opportunities for entrepreneurship, 
market entry and growth, innovation, labor and much more (Klein, 3008 p.1).

Housing is an area that presents a business opportunity to create instrumental and intrinsic wealth (profit and wellness). Non-profit housing in Australia has delivered outcomes that suggest that social housing is viable.

Beginning as small scale and minor players, in recent years a number of these organisations (upwards of 40) have expanded their capacity to develop, finance and manage major housing projects. Increasingly governments across Australia are considering these entrepreneurial organisations as preferred providers of affordable housing (Tomlinson, 2013 p.60).

Similar housing initiatives are being developed here in New Zealand. Ngā Pōtiki is a small post Treaty Settlement tribe who is working collaboratively with the New Zealand government to develop affordable housing in their community. Their tribal estate is in Tauranga one of the more affluent cities in New Zealand. Ngā Pōtiki a Tamapāhore Trust reported that:

Tauranga is one of the most unaffordable cities in New Zealand to live in. The average house costs 6 times the average annual salary and 11 times the average Maori annual salary. As the cost of home ownership becomes unaffordable so too does the cost of rental housing (Ngā Pōtiki a Tamapāhore Trust, 2013 p.1).

High decile ${ }^{5}$ areas such as Tauranga include enclaves of deprivation that are typically Māori. However, poverty is cross

\footnotetext{
${ }^{5}$ Indices of wealth based on NZDep Index
} 
cultural and cross class and in acknowledgement of this, and in the spirit of altruism, Ngā Pōtiki a Tamapāhore Trust housing developments are open to the entire community. This not only makes sound business sense because it expands the market but the inclusivity breaks down social barriers within a community. The Tapuika tribal estate (te takapū o Tapuika) borders those of Ngā Pōtiki. The close kinship relationship between Ngā Pōtiki and Tapuika reflects geographical proximity and inevitable marriage alliances between the two tribes.

As a result of the 'kinship' relationship negotiations are now under way for the tribes to collaborate on the housing project initiative. Members of Tapuika have access to Ngā Pōtiki housing services but the objective of developing a formal alliance is to avoid replication. Tapuika could develop its own housing portfolio. Instead, there is potential for both tribes to strengthen their position and achieve government preferred provider status of affordable housing. It is plausible that the initiative could go beyond tribal boundaries. Interestingly, this spirit of collaboration is not confined to post-Treaty settlement tribes.

For example, although there is no formal relationship between Ngā Kākano Foundation' ${ }^{6}$ and the Treaty PSGE; Tapuika Iwi Authority (TIA), both organisations are closely affiliated. Ngā Kākano is identified as a Tapuika health provider that has always had a policy of delivering health services to the entire community. In the last decade the ethnic profile of $\mathrm{Te}$ Puke has become more diverse. Minority ethnic groupings now include African, Asian, Pacific island, Hispanic and Middle Eastern residents. This diversity is reflected in the organisation's client statistical database. Māori make up approximately $70 \%$ of the total client base, Pākehā $20 \%$ with a mix of minority groups accounting for the remaining $10 \%$. These peoples all tend to be marginalised and are attracted to the Te Puke district to work in the kiwi fruit industry, as unskilled

\footnotetext{
${ }^{6}$ Established in 1986 Ngā Kākano is a health provider whose philosophy, beliefs and values are embedded in Tapuika culture
} 
labour. Because they occupy the lower socio-economic stratum in the community they also present with the range of health issues associated with deprivation.

Joint ventures in housing, health and employment between governments, NGO's, business and the community demonstrate the amenability of tribal organisations to CSR principles.

\section{CONCLUSION}

Let us choose to unite the power of markets with the authority of universal ideals. Let us choose to reconcile the creative forces of private entrepreneurship with the needs of the disadvantaged and the requirements of future generations. Kofi Annan (1998).

CSR is not a panacea for wealth creation and in this sense wealth refers to spiritual, physical, social and cultural wellbeing. Organisations that are committed to CSR are reliant on 'good' governance and sound management practices to deliver a double bottom line on social and financial performance. The commonality between CSR and Māori tribal organisations is both aspire to improve the wellbeing, in all its multifarious forms, of the communities they serve. Consequently, post-Treaty tribal governance organisations are involved in both profit and non-profit making initiatives. This creates tension between social/cultural values and growing tribal wealth. This tension is amplified when considered within the context Māori of poverty and unwellness.

The principles of CSR present a strategy to creatively address the challenges that this presents. Adding yet another dimension to CSR Spiller, Erakovic, Henare and Pio (2011) offer a comprehensive and relational definition of wealth that is embedded in a wellness framework. 
Business can create, spiritual, cultural, social environmental and economic wellbeing. A well-beings approach entails praxis, which brings values and practice together with the purpose of consciously creating wellbeing and, in so doing, creates multidimensional wealth (p.153).

This well-beings approach provides a solution to the mana or money dilemma that beleaguers post-Treaty Māori tribal organisations. By adopting a CSR/well-being agenda, Māori Collective organisations can potentially deliver a triple bottom line on social, financial and cultural performance. The spirit of collaboration is the social glue that brings government, NGO's, business and tribes together to effect spiritual, cultural, social environmental and economic wellbeing. 


\section{Bibliography}

Anaya, J. (2011). Report of the Special Rapporteur on the rights of indigenous peoples. The situation of the Maori people in NZ. New York: United Nations General Assembly.

Annan, K. (1998). Markets for a Better World. Key Note Speech. Davos, Switzerland: World Economic Forum.

Arena, C. (2004). Cause for Success: Ten Companies That Have Put Profits Second and Come in First. California: New World Library.

Boyle, M. \& Boguslaw, J. (2007). Business, Poverty and Corporate Citizenship Naming the Issues and Framing Solutions. Journal of Corporate Citizenship Vol. 26 pp. $101-120$.

Carroll, A. B., \& Shabana, K. M. (2010). The business case for corporate social responsibility: A review of concepts, research and practice. International Journal of Management Reviews, 12 (1), 85-105.

Dalziel, P., Matunga, H. \& Saunders, C. (2006). Cultural well-being and local government: Lessons from New Zealand. In Australasian Journal of Regional Studies, 12(3), 267-280.

Durie, M. (1998) Te Mana, Te Kawanatanga: The Politics of Mãori SelfDetermination. Auckland: Oxford University Press.

Friedman, M. (1962) Capitalism and Freedom, 40th Anniversary Edition. Chicago: University of Chicago Press.

Graham, D. (1997). Trick or Treaty? Wellington: Institute of Policy Studies.

Griswold, C. (1999). Adam Smith and the Virtues of the Enlightenment. Cambridge: Cambridge University Press.

Hopkins, M. (2003). The Planetary Bargain: Corporate Social Responsibility Matters. London: Earthscan.

Henderson, D. (2001). Misguided Virtue: False Notions of Corporate Social Responsibility. London: Institute of Economic Affairs.

Hall, G. \& Patrinos, H. (2014). Indigenous Peoples, Poverty and Development. Cambridge: Cambridge University Press.

Jackson, K. (2004). Building Reputational Capital: Strategies for Integrity and Fair Play That Improve the Bottom Line. Oxford: Oxford University Press.

Kahn, C. (1979). The Art and Thought of Heraclitus. London: Cambridge University Press.

Klein, M. (2008). Poverty Alleviation through Sustainable Strategic Business Models Rottendam: Erasmus Research Institute of Management (ERIM) Erasmus University.

Law Commission (2002). An Advisory Report for Te Puni Kōkiri. The Office of the Treaty Settlements and the Chief Judge of the Māori Land Court Treaty of Waitangi Claims: Addressing the PostSettlement Phase. August Study

May, S. Cheney, G. Roper, J. EDS. (2007). The Debate over Social Responsibility. New York: Oxford University Press.

Machiavelli, N. (1996). Discourses on Livy. Translated by Harvey C. Mansfield and Nathan Tarcov. Chicago: University of Chicago Press.

Machiavelli (1980). The Prince. Translated by Leo Paul S. de Alvarez. Prospect Heights: Waveland Press. 
McNeill, H., Aspin, C., \& Kingi, T. K. (2009). Health measurement and knowledge translation for improved Māori health outcomes. Auckland: Health Research Council.

Moon, P. (2014). The Influence of 'Benthamite' Philosophies on British Colonial Policy on New Zealand in the Era of the Treaty of Waitangi. Journal of Imperial and Commonwealth History, (ahead-of-print), 120.

New Zealand Government (13 January 2012): Treasury Report Data on Poverty in New Zealand. Report Number T2012/47. http://www.dpmc.govt.nz/sites/all/files/publications/2397303mcop-tr-data-on-poverty-in-nz.pdf

New Zealand Herald. 8 September 2011. Bank Eyes \$37b Maori Economy.

New Zealand Herald. 26 February 2015. Prospects appear even brighter for Maori Economic Renaissance.

Ngā Pōtiki a Tamapāhore Trust (2013). Submissions on consultation document 'A Regulatory Framework for Community Housing Providers. http://www.shu.govt.nz/assets/CHRA-Documentsand-photos/Submissions/Nga-Potiki-A-Tamapahore-TrustSubmission.pdf.

Office of Treaty Settlements. Post Settlement Governance Entities: A Guide http: / / www.ots.govt.nz/

Orange, C. (2011). The Treaty of Waitangi. Wellington: Bridget Williams Books.

Parva, M.L. and J. Krausz (1995). Corporate Responsibility and Financial Performance: The Paradox of Social Cost, Quorum, Connecticut.

Poitras, G. (1994). Shareholder Wealth Maximization, Business Ethics and Social Responsibility. Journal of Business Ethics, 13:125-34.

Reich, R. (2008). The Case Against Corporate Social Responsibility. California: Goldman School Working Paper Series. University of California Berkley.

Russo, M. \& Fouts, P. (1997). A Resource Perspective on Corporate Environmental Performance and Profitability.' Academy of Management Journal 40 (3) pp. 534-559.

Sen, A. (1987). On Ethics and Economics. Oxford: Blackwell.

Senge P. (1990). The Fifth Discipline: The Art \& Practice of the Learning Organization. New York: Currency Doubleday.

Senge, P, Smith, B. Kruschwitz, N. Laur, J. \& Schley, S (2010). The Necessary Revolution: How Individuals and Organisations are working together to create a Sustainable World. London: Brealey Publishing.

Smith, A. (1976). The Theory of Moral Sentiments. Rapahel, D. and Macfie, A. (Eds.), Oxford:

Clarendon Press.

Spiller C. Erakovic, L. Henare M. and Pio E. (2011). Relational WellBeing and Wealth: Māori Businesses and an Ethic of Care. Journal of Business Ethics, Vol. 98, Issue 1, pp. 153-169. 
Stavenhagen, R. (2006). Report of the Special Rapporteur on the situation of human rights and

fundamental freedoms of indigenous people. New York: United Nations General Assembly.

Tapuika Deed of Settlement Act (2014). New Zealand Government. http://www.tapuika.iwi.nz/images/uploads/Tapuika_Deed_of_Se ttlement_Clean_Final_changes_16_Oct.p

Television New Zealand Archive. (1988). Mokoia Waka Huia Documentary. Producer: Whai Ngata.

Tomlinson, R. (Ed). (2012). Australia's Unintended Cities: the Impact of Housing on Urban Development. Melbourne: CSIRO publishing.

Vivos, A. (2004). The role of multilateral development institutions in fostering corporate social responsibility. Development 47: 3 pp.4552.

Vogel, D. (2005). The Market for Virtue: The Potential and Limits of Corporate Social

Responsibility. Washington: Brookings Institution.

Wells, T. (2014). Recovering Adam Smith's ethical economics. Real World Economics Review, Issue 68. pp. 90 - 98.

Whaley, F. (2013). Is corporate social responsibility profitable for companies? https://www.devex.com/news/is-corporate-socialresponsibility-profitable-for-companies-80354

Willard, R. (2002). The Sustainability Advantage: Seven Business Case Benefits of a Triple Bottom Line. British Colombia: New Society.

Young, W. \& Tilley, F. (2006). Can businesses move beyond efficiency? The shift toward effectiveness and equity in the corporate sustainability debate. Business Strategy and the Environment, 15(6), 402-415.

Yunus Muhammad. (2008). Creating a World without poverty: Social Business and the Future of Capitalism. Global Urban Development Magazine. Volume 2, Issue 2. pp.16 -41 \#136909 